\title{
给电子基团对吲哚染料电子结构和吸收光谱的影响
}

\author{
梁桂杰 ${ }^{1,2, *}$ 钟志成 ${ }^{1, *}$ 陈美华 ${ }^{1}$ 许 杰 $^{3}$ 徐卫林 ${ }^{3}$ \\ 和平 ${ }^{1}$ 候秋飞 ${ }^{1}$ 李在房 ${ }^{1}$ \\ ('湖北文理学院材料科学与工程研究中心, 湖北襄阳 441053; “西安交通大学金属材料强度国家重点实验室, 西安 710049; \\ 3 武汉纺织大学新型纺织材料绿色加工及其功能化教育部重点实验室, 武汉 430073)
}

\begin{abstract}
摘要：利用密度泛函理论(DFT)和含时密度泛函理论(TD-DFT), 分别基于 B3LYP 和PBE1PBE 方法研究了一 系列含有不同给电子基团的吲哚染料分子(ID1-ID3)的电子结构和吸收光谱性质. 重点比较了不同电子给体对 染料的分子结构、吸收光谱以及其在电池中的光伏性能的影响. 结果表明从 ID1、ID2 到 ID3, 随着电子给体中苯 环数目的增加, 吲哚分子上的共轭效应逐渐增大, 导致吲哚分子最高占据分子轨道-最低未占据分子轨道 (HOMO-LUMO)之间的能隙变窄, 分子的吸收光谱发生红移. 染料分子的吸收光谱和 LUMO 能级分别影响染料 的吸光效率和光电转化过程中电子的注入过程, 从而使其二者成为决定电池光伏性能的重要参数. 综合考虑上 述两个参数对电池性能的贡献, 通过理论研究证实, 在 ID1-ID3系列染料中, ID3 具有较长的吸收谱带、较大的 分子消光系数和合适的 LUMO 能级, 从而表现出最为优越的光伏性能, 这与实验得出的结论很好地吻合.
\end{abstract}

关键词： 密度泛函理论; 染料敏化太阳能电池; 吲哚染料; 分子结构; 吸收光谱 中图分类号: 0641

\section{Effect of Donor Moieties on the Electronic Structures and Absorption Spectra of Indoline Dyes}
LIANG Gui-Jie ${ }^{1,2, *}$
ZHONG Zhi-Cheng ${ }^{1, *}$
CHEN Mei-Hua ${ }^{1}$
$\mathrm{XU} \mathrm{\textrm {Jie } ^ { 3 }}$
XU Wei-Lin ${ }^{3}$
HE Ping ${ }^{1}$
HOU Qiu-Fei ${ }^{1}$
LI Zai-Fang

('Research Center for Materials Science \& Engineering, Hubei University of Arts and Science, Xiangyang 441053, Hubei Province,

P. R. China; ${ }^{2}$ State Key Laboratory for Mechanical Behavior of Materials, Xi'an Jiaotong University, Xi'an 710049, P. R. China;

${ }^{3}$ Key Laboratory of Green Processing and Functional Textiles of New Textile Materials, Ministry of Education,

Wuhan Textile University, Wuhan 430073, P. R. China)

\begin{abstract}
The electronic structures and absorption spectra of indoline dyes containing different donors (ID1-ID3) were investigated by density functional theory (DFT) and time-dependent DFT, at the B3LYP and PBE1PBE levels, respectively. The effects of the donor moieties on the molecular structures, absorption spectra, and photovoltaic performance have been compared. The results indicate the increase in the number of phenyl groups in the donor decreases the highest occupied molecular orbital-the lowest unoccupied molecular orbital (HOMO-LUMO) energy gap and red-shifts the absorption band. This is related to the increased conjugation from ID1 to ID2 and ID3. The absorption spectra and LUMO energy level act as two criteria for the photovoltaic performance of a dye by determining the light harvesting efficiency and charge injection process, respectively. Considering the above two factors' contribution to the performance of a photovoltaic cell, ID3 with a long absorption band and high extinction coefficient, as well as a favorable
\end{abstract}

Received: March 15, 2012; Revised: May 30, 2012; Published on Web: May 30, 2012.

"Corresponding authors. LIANG Gui-Jie, Email: lgj511011@163.com; Tel: +86-15971164180.

ZHONG Zhi-Cheng, Email: zczhongf@163.com; Tel: +86-710-3590061.

The project was supported by the National Natural Science Foundation of China (51003082), Key Project of Science and Technology Research of Ministry of Education, China (208089), and Natural Science Foundation of Hubei Province, China (2011CDC062).

国家自然科学基金(51003082), 教育部科学技术研究重点项目(208089)和湖北省自然科学基金(2011CDC062)资助

(C) Editorial office of Acta Physico-Chimica Sinica 
LUMO energy level has been confirmed theoretically to be the best dye of ID1-ID3, which is consistent with experiment results.

\section{Key Words: Density functional theory; Dye-sensitized solar cell; Indoline dye; Molecular structure; Absorption spectrum}

\section{Introduction}

Recently, dye-sensitized solar cells (DSSCs) have attracted much attention as possible alternatives to conventional solid-state photovoltaic devices owing to their potentially low fabrication cost and relatively high conversion efficiencies. ${ }^{1-5}$ Acting as photosensitizer in the DSSCs, the dye is one of the key components for high solar-to-electric conversion efficiencies of the cells. The performances of dyes, such as light harvesting efficiency, quantum yield of electron injection on the surface of semiconductor film, and so on, are of great importance to determine the efficiency of the DSSCs. In order to design and synthesize more efficient sensitizing dyes, it is necessary to understand the electronic structures of the existing dyes.

There are several types of dyes used in DSSCs among which polybipyridyl ruthenium complex dyes exhibit the relatively better charge-transfer (CT) performance and higher conversion efficiency. ${ }^{6}$ However, the large-scale application of the Ru complexes are limited due to their materials costs and environment problem. Then, many organic dyes for DSSCs, including cyanine dyes, ${ }^{7}$ porphyrin dyes, ${ }^{8}$ phthalocyanine dyes, ${ }^{9}$ and coumarin dyes ${ }^{10}$ are also reported because of their lower cost, more environment harmony, and more convenient synthesis process compared with the Ru complexes. Indoline dyes have been experimentally prepared as one kind of promising organic dyes with high conversion efficiency for DSSCs. ${ }^{11-14}$ Experimental synthesis method is a powerful and straightforward route to get new dyes; however, the process is not only expensive but also time-consuming. Density functional theory (DFT) method is another effective tool for theoretical treatment of structures as well as electronic and absorption spectra. Its time- dependent extension, called time-dependent DFT (TD-DFT), can give reliable values for the valence excitation energies with standard exchange-correlation functionals. Ham et al. ${ }^{15}$ designed and studied a group of indoline dyes derived from the D149 through DFT/TD-DFT calculations, and the results provided useful clues for the molecular engineering of efficient organic dye sensitizers. Le Bahers et al. ${ }^{16}$ investigated three indoline dyes D131, D102, and D149 with different acceptors by DFT, and found that the computed results agreed well with the experimental results; the calculations allowed new insights into the electronic structure of this indoline dye family.

In this work, DFT and TD-DFT calculations were employed to study the electronic structures and optical properties of a series of indoline dyes with different donors including indoline dye 1 (ID1: $\mathrm{C}_{24} \mathrm{H}_{22} \mathrm{~N}_{2} \mathrm{O}_{4} \mathrm{~S}_{2}$ ), indoline dye 2 (ID2: $\mathrm{C}_{28} \mathrm{H}_{22} \mathrm{~N}_{2} \mathrm{O}_{4} \mathrm{~S}_{2}$ ), indoline dye 3 (ID3: $\mathrm{C}_{37} \mathrm{H}_{30} \mathrm{~N}_{2} \mathrm{O}_{3} \mathrm{~S}_{2}$ ). The efficient sensitized mechanism of the indoline dyes was elucidated and the influence of different donors on the electronic and optical properties of indoline dyes was investigated in detail. Further, the relationships between the theoretical parameters of indoline dyes and the experimental efficiency of cells were also discussed.

\section{Computational methods}

The structures of the dyes ID1, ID2, and ID3 were pre-optimized using the semi-empirical AM1 method. ${ }^{17}$ The final ground-state geometries were obtained without any symmetry constrains at the Becke's three parameter gradient-corrected exchange potential and the Lee-Yang-Parr gradient-corrected correlation potential (B3LYP $)^{18}$ level of theory with the $6-31 \mathrm{~g}(d)$ basis set. A full natural bond orbital (NBO) analysis was employed by using the $\mathrm{POP}=\mathrm{NBO}$ keyword, along with a second-order perturbation theory (SOPT) analysis. The excitation energies and oscillator strengths for the lowest 30 singlet-singlet transitions at the optimized geometry were obtained by TDDFT $^{19}$ calculations with the hybrid functionals B3LYP and PBE1PBE ${ }^{20}$ respectively, by the same basis set as for the ground state. According to the calculated results, the UV-Vis absorption spectra were simulated by means of the SWizard program (Revision 4.6) using a Gaussian convolution with the full width at half-maximum of $3500 \mathrm{~cm}^{-1}$. The conductor polarizable continuum model $(\mathrm{CPCM})^{21}$ was employed in this program to introduce the solvation effect of ethanol on the dyes. All calculations were performed with the Gaussian 03 program package. $^{22}$

\section{Results and discussion}

\subsection{Molecular geometries}

As shown in Fig.1, the structures of ID1-ID3 all have a typical D- $\pi$-A (D: donor, $\pi$ : conjugated body, A: acceptor) structure. They have the same conjugated bodies (cyclopentyl indole-rhodanine) and acceptors (acetic acid), while the different donors ( $\mathrm{R} x=$ methoxyphenyl, methoxynaphthyl, and diphenylvinylphenyl, for ID1, ID2, and ID3).

The optimized geometrical structures in the ground state of indoline dyes are shown in Fig.2, and some of the calculated bond lengths, bond angles, and dihedral angles of the dyes are listed in Table 1. Most of the corresponding parameters are consistent with the calculated results for the indoline dyes, ${ }^{16,23,24}$ reflecting the reasonability of the present results. All $\mathrm{C}-\mathrm{C}$ lengths in the rhodanine, indoline unit and phenyl rings are between the distance of a single bonded $\mathrm{C}-\mathrm{C}$ and a double bonded $\mathrm{C}=\mathrm{C}$, implying that there is extensive delocalization throughout 
(a)<smiles>[R1]N1c2ccc(/C=C3\SC(=S)N(CC(=O)O)C3=O)cc2C2CCCC21</smiles><smiles>COc1ccc(C)cc1</smiles>

(c)<smiles>COc1ccc2cc(C)ccc2c1</smiles>

(d)<smiles>Cc1ccc(C=C(c2ccccc2)c2ccccc2)cc1</smiles>

R1=methoxyphenyl, R2=methoxynaphthyl, R3=diphenylvinylphenyl

Fig.1 Molecular structures of indoline dyes (a) and the different donor moieties $\mathrm{R} x(x=1,2,3)$ of R1 for ID1 (b), R2 for ID2 (c), and R3 for ID3 (d)

the molecule of the indoline dyes. It can be concluded that these dyes are fully conjugated through the $\pi$-system from the donor to the conjugated body and the acceptor. The delocalization phenomena and the conjugate structure are beneficial to the intramolecular charge transfer (CT) and to the stability of the molecule. The substrates (conjugated body and the acceptor) of the three indoline dyes (ID1-ID3) have almost the same geometric character including the similar bond lengths, bond angles, and dihedral angles, as shown in Table 1. However, with increase of the phenyl number in the donor, the geometric structure of the whole dye undergoes some changes from each other, such as the calculated conjugated chain length throughout the molecule (ID1: $L(18 \mathrm{C}-39 \mathrm{O})=1.534 \mathrm{~nm}$, ID2: $L(18 \mathrm{C}-32 \mathrm{O})=1.763 \mathrm{~nm}$, and ID $3: L(18 \mathrm{C}-30 \mathrm{C})=1.788 \mathrm{~nm})$ as well as the dihedral angle between the planes of donor and substrate $\left(\mathrm{ID} 1: \mathrm{D}(15 \mathrm{C} 19 \mathrm{C} 36 \mathrm{~N} 3 \mathrm{C})=139.7^{\circ}\right.$, ID $2: D(27 \mathrm{C} 22 \mathrm{C} 4 \mathrm{~N} 3 \mathrm{C})=$ $148.1^{\circ}$ and ID3: $\left.D(25 \mathrm{C} 24 \mathrm{C} 4 \mathrm{~N} 3 \mathrm{C})=149.5^{\circ}\right)$ increase gradually from ID1 to ID2 and ID3, which could be ascribed to the prolonged $\pi$ conjugated system and the enhancement of the steric hindrance induced by the increase of phenyl number in the donor, respectively.

\subsection{Electronic structures}

Table 1 Selected bond lengths ( $L$ in $\mathrm{nm})$, bond angles ( $A$ in degree), and dihedral angles ( $D$ in degree) for the dyes ID1, ID2, and ID3 calculated at the B3LYP/6-31g(d) level

\begin{tabular}{lcllll}
\multicolumn{7}{c}{ calculated at the B3LYP/6-31g( level } \\
\hline \multicolumn{1}{c}{ ID1 } & \multicolumn{1}{c}{ ID2 } & \multicolumn{2}{c}{ ID3 } \\
\hline$L(17 \mathrm{C}-37 \mathrm{~N})$ & 0.145 & $L(17 \mathrm{C}-13 \mathrm{~N})$ & 0.145 & $L(17 \mathrm{C}-13 \mathrm{~N})$ & 0.145 \\
$L(10 \mathrm{C}-7 \mathrm{C})$ & 0.143 & $L(10 \mathrm{C}-7 \mathrm{C})$ & 0.144 & $L(10 \mathrm{C}-7 \mathrm{C})$ & 0.144 \\
$L(36 \mathrm{~N}-3 \mathrm{C})$ & 0.137 & $L(4 \mathrm{~N}-3 \mathrm{C})$ & 0.138 & $L(4 \mathrm{~N}-3 \mathrm{C})$ & 0.138 \\
$L(36 \mathrm{~N}-5 \mathrm{C})$ & 0.148 & $L(4 \mathrm{~N}-5 \mathrm{C})$ & 0.148 & $L(4 \mathrm{~N}-5 \mathrm{C})$ & 0.148 \\
$L(18 \mathrm{C}-39 \mathrm{O})$ & 1.534 & $L(18 \mathrm{C}-32 \mathrm{O})$ & 1.763 & $L(18 \mathrm{C}-30 \mathrm{C})$ & 1.788 \\
$A(17 \mathrm{C}-37 \mathrm{~N}-12 \mathrm{C})$ & 119.8 & $A(17 \mathrm{C}-13 \mathrm{~N}-12 \mathrm{C})$ & 119.8 & $A(17 \mathrm{C}-13 \mathrm{~N}-12 \mathrm{C})$ & 119.9 \\
$A(10 \mathrm{C}-7 \mathrm{C}-6 \mathrm{C})$ & 117.3 & $A(10 \mathrm{C}-7 \mathrm{C}-6 \mathrm{C})$ & 117.3 & $A(10 \mathrm{C}-7 \mathrm{C}-6 \mathrm{C})$ & 117.4 \\
$A(19 \mathrm{C}-36 \mathrm{~N}-3 \mathrm{C})$ & 127.5 & $A(22 \mathrm{C}-4 \mathrm{~N}-3 \mathrm{C})$ & 127.6 & $A(24 \mathrm{C}-4 \mathrm{~N}-3 \mathrm{C})$ & 128.0 \\
$D(12 \mathrm{C} 37 \mathrm{~N} 17 \mathrm{C} 18 \mathrm{C})$ & 98.7 & $D(12 \mathrm{C} 13 \mathrm{~N} 17 \mathrm{C} 18 \mathrm{C})$ & 98.9 & $D(12 \mathrm{C} 13 \mathrm{~N} 17 \mathrm{C} 18 \mathrm{C})$ & 101.6 \\
$D(6 \mathrm{C} 7 \mathrm{C} 10 \mathrm{C} 11 \mathrm{C})$ & 178.4 & $D(6 \mathrm{C} 7 \mathrm{C} 10 \mathrm{C} 11 \mathrm{C})$ & 178.7 & $D(6 \mathrm{C} 7 \mathrm{C} 10 \mathrm{C} 11 \mathrm{C})$ & 177.8 \\
$D(15 \mathrm{C} 19 \mathrm{C} 36 \mathrm{~N} 3 \mathrm{C})$ & 139.7 & $D(27 \mathrm{C} 22 \mathrm{C} 4 \mathrm{~N} 3 \mathrm{C})$ & 148.1 & $D(25 \mathrm{C} 24 \mathrm{C} 4 \mathrm{~N} 3 \mathrm{C})$ & 149.5 \\
\hline
\end{tabular}
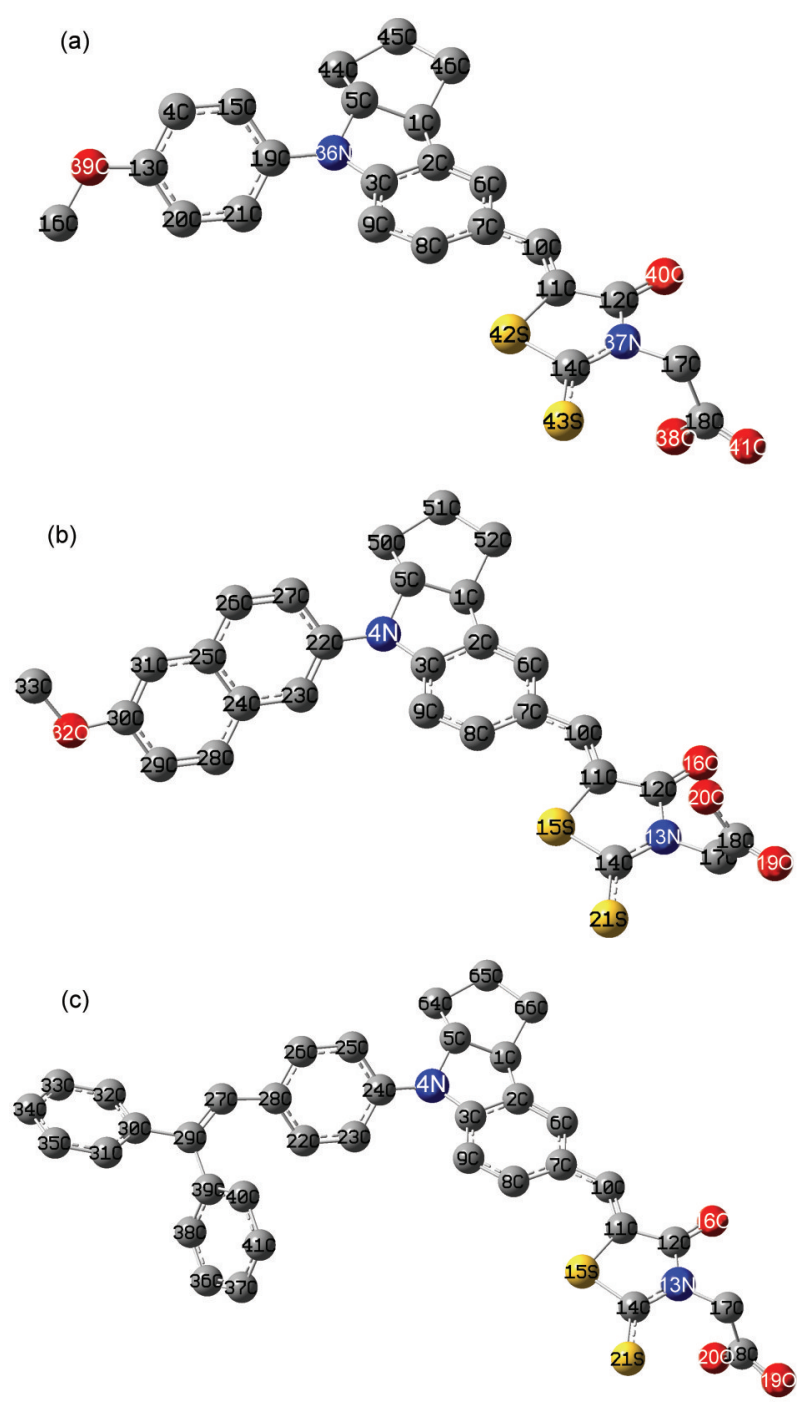

Fig.2 Optimized ground state geometries of the indoline dyes (a) ID1, (b) ID2, (c) ID3; $\mathrm{H}$ atoms are not shown for clarity.

Natural bond orbital (NBO) analysis was carried out to analyze the intramolecular CT in ID1-ID3. In order to further characterize the CT capability of the indoline dyes, a second-order perturbation theory (SOPT) analysis of the Fock matrix within the NBO basis was performed. According to the NBO donor- 
Table 2 Conjugative interaction energies $\left(\Delta E^{(2)}\right)$ between the $\pi$-bonding and $\pi^{*}$-antibonding orbitals in ID1-ID3 based on second-order perturbation theory analysis of the Fock matrix for the NBO analysis

\begin{tabular}{lllc}
\hline Dye & Donor orbital & Acceptor orbital & $\Delta E^{21} /\left(\mathrm{kJ} \cdot \mathrm{mol}^{-1}\right)$ \\
\hline ID1 & $\pi(3 \mathrm{C}=9 \mathrm{C})$ & $\pi^{*}(7 \mathrm{C}=8 \mathrm{C})$ & 104.69 \\
& $\pi(7 \mathrm{C}=8 \mathrm{C})$ & $\pi^{*}(10 \mathrm{C}=11 \mathrm{C})$ & 92.54 \\
& $\pi(10 \mathrm{C}=11 \mathrm{C})$ & $\pi^{*}(12 \mathrm{C}=40 \mathrm{O})$ & 104.85 \\
ID2 & $\pi(3 \mathrm{C}=9 \mathrm{C})$ & $\pi^{*}(7 \mathrm{C}=8 \mathrm{C})$ & 105.86 \\
& $\pi(7 \mathrm{C}=8 \mathrm{C})$ & $\pi^{*}(10 \mathrm{C}=11 \mathrm{C})$ & 93.72 \\
& $\pi(10 \mathrm{C}=11 \mathrm{C})$ & $\pi^{*}(12 \mathrm{C}=16 \mathrm{O})$ & 105.69 \\
ID3 & $\pi(3 \mathrm{C}=9 \mathrm{C})$ & $\pi^{*}(7 \mathrm{C}=8 \mathrm{C})$ & 106.53 \\
& $\pi(7 \mathrm{C}=8 \mathrm{C})$ & $\pi^{*}(10 \mathrm{C}=11 \mathrm{C})$ & 94.14 \\
& $\pi(10 \mathrm{C}=11 \mathrm{C})$ & $\pi^{*}(12 \mathrm{C}=16 \mathrm{O})$ & 105.94 \\
\hline
\end{tabular}

acceptor interaction theory, the directly estimated approach of $\pi$-conjugative stable energies using SOPT analysis will be very helpful to analyze the $\pi$-conjugation strength. Then, the sum of stabilization energies can be defined as the indicator of the degree of the $\pi$-conjugation of ID1-ID3. The energies of the $\pi \rightarrow$ $\pi^{*}$ conjugative interactions in the selected bonds taken from the NBO analysis are given in Table 2 . As shown by the NBO parameters listed, the stabilization energies rise up from ID1 to ID2 and ID3. So, it can be easily observed that with the phenyl number increasing in the donor moieties, the conjugation effect increases in the molecule of ID1-ID3, which is of significance to the molecular electron-transfer and then the photoelectric conversion efficiency of the dyes, although there is some decrease of the co-planarity between the donor and substrate induced by the steric hindrance of phenyl groups.

The frontier molecular orbital (MO) contribution is very important in determining the charge-separated states of dyes. The MOs involved in the analyzed transition of ID1-ID3 were examined in detail. The structures of the highest occupied molecular orbital (HOMO) and the lowest unoccupied molecular or-

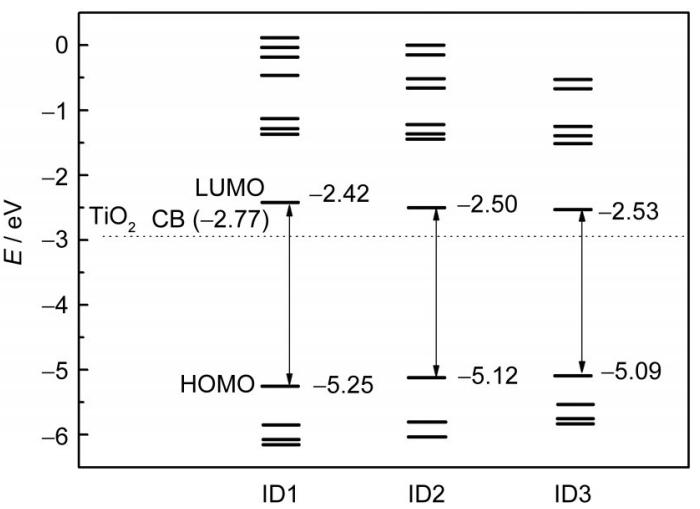

Fig.4 Calculated energy levels of molecular orbitals of ID1-ID3

bital (LUMO) of the three indoline dyes are displayed in Fig.3. For the dyes ID1-ID3, HOMOs are the $\pi$ orbital delocalized over the entire molecule, whereas LUMOs are the $\pi^{*}$ orbital localized mainly in cyclopentyl indole and rhodanine acetic acid groups. The LUMO possesses larger composition of rhodanine acetic acid group (extended acceptor) compared with the HOMO which is liable to located at the oxo-thioxothiazolidinyl group and the $\mathrm{R} x$-substituent (donor), indicating the excited electrons transfer from the donor moieties to the acceptor groups during the HOMO-LUMO excitation in ID1-ID3. The electron transfer path presented above fits the electron injection process from oxidized dye to semiconductor in DSSCs as the dyes are anchored onto the surface of the semiconductor through the carboxyl group. So, the electronic structures of ID1-ID3 are proved to be suitable for the high overall efficiency in DSSCs.

The calculated absolute energies of the HOMOs are -5.25 , -5.12 , and $-5.09 \mathrm{eV}$, while those of the LUMOs are $-2.42,-2.50$, and $-2.53 \mathrm{eV}$ respectively for ID1, ID2, and ID3, as shown in Fig.4. The LUMO levels of ID1, ID2, and ID3 are all suffi-

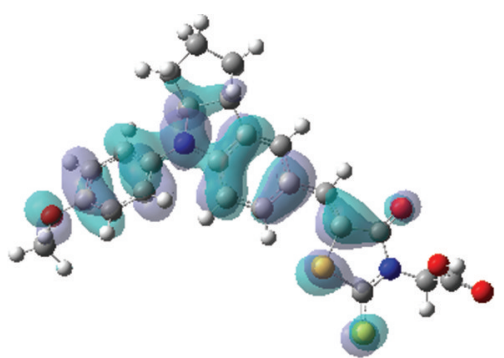

ID1 HOMO

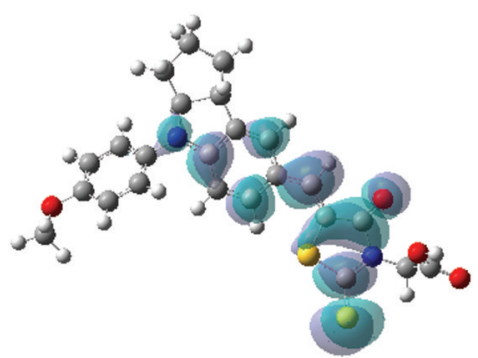

ID1 LUMO

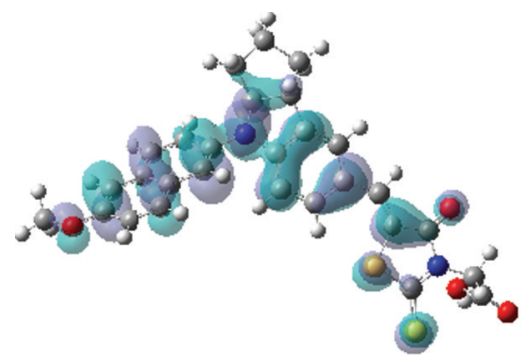

ID2 HOMO

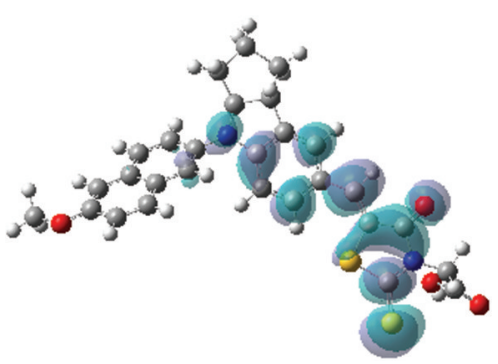

ID2 LUMO

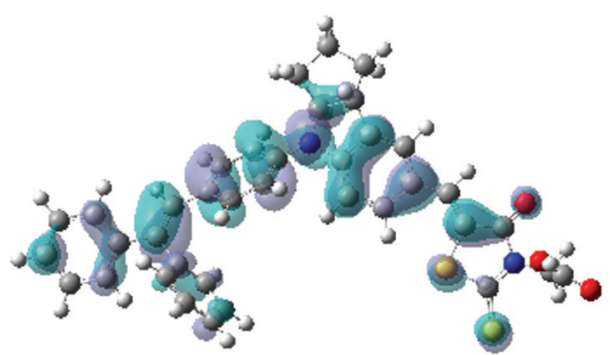

ID3 HOMO

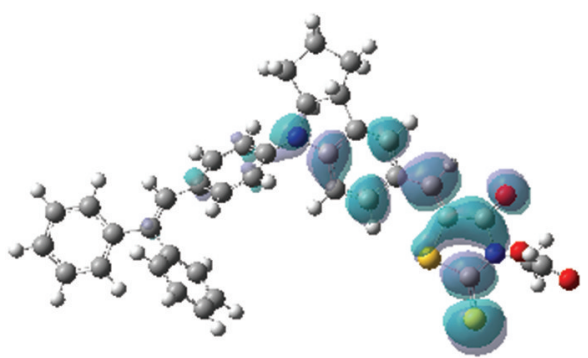

ID3 LUMO

Fig.3 Structures of frontier orbitals for ID1-ID3 
No.8 LIANG Gui-Jie et al:: Effect of Donor Moieties on the Electronic Structures and Absorption Spectra of Indoline Dyes 1889

Table 3 Computed excitation energies, electronic transition configurations, and oscillator strengths for the optical transitions with $f_{\text {singlet }}>0.1$ of the UV-Vis absorption bands for the dyes with PBE1PBE

\begin{tabular}{|c|c|c|c|c|c|}
\hline & & Configurations composition with $\mid$ CI Coeff. $\mid>0.2$ (corresponding transition orbitals) & $E^{\mathrm{a}} /\left(\mathrm{eV} \cdot \mathrm{nm}^{-1}\right)$ & $f^{\mathrm{b}}$ & Assignment \\
\hline \multirow{6}{*}{ ID1 } & 1 & $0.667(\mathrm{H} \rightarrow \mathrm{L})$ & $2.64 / 469$ & 0.744 & $\pi \rightarrow \pi^{*}$ \\
\hline & 2 & $-0.225(\mathrm{H}-2 \rightarrow \mathrm{L}) ; 0.629(\mathrm{H}-1 \rightarrow \mathrm{L})$ & $3.44 / 359$ & 0.281 & \\
\hline & 3 & $-0.173(\mathrm{H}-5 \rightarrow \mathrm{L}) ; 0.241(\mathrm{H}-3 \rightarrow \mathrm{L}) ; 0.592(\mathrm{H} \rightarrow \mathrm{L}+1)$ & $3.99 / 310$ & 0.109 & \\
\hline & 4 & $-0.149(\mathrm{H}-5 \rightarrow \mathrm{L}) ; 0.557(\mathrm{H}-3 \rightarrow \mathrm{L}) ; 0.139(\mathrm{H}-2 \rightarrow \mathrm{L})$ & $3.99 / 310$ & 0.101 & \\
\hline & 5 & $0.116(\mathrm{H}-7 \rightarrow \mathrm{L}) ;-0.216(\mathrm{H}-5 \rightarrow \mathrm{L}) ;-0.110(\mathrm{H}-3 \rightarrow \mathrm{L})$ & $4.57 / 270$ & 0.163 & \\
\hline & 6 & $-0.335(\mathrm{H} \rightarrow \mathrm{L}+4) ; 0.578(\mathrm{H} \rightarrow \mathrm{L}+5)$ & $4.99 / 248$ & 0.135 & \\
\hline \multirow[t]{7}{*}{ ID2 } & 1 & $0.661(\mathrm{H} \rightarrow \mathrm{L})$ & $2.46 / 502$ & 0.948 & $\pi \rightarrow \pi^{*}$ \\
\hline & 2 & $0.674(\mathrm{H}-1 \rightarrow \mathrm{L})$ & $3.25 / 380$ & 0.316 & \\
\hline & 3 & $-0.258(\mathrm{H}-2 \rightarrow \mathrm{L}) ; 0.500(\mathrm{H} \rightarrow \mathrm{L}+1)$ & $3.65 / 339$ & 0.103 & \\
\hline & 4 & $-0.265(\mathrm{H}-2 \rightarrow \mathrm{L}) ; 0.232(\mathrm{H} \rightarrow \mathrm{L}+1) ; 0.551(\mathrm{H} \rightarrow \mathrm{L}+2)$ & $3.83 / 323$ & 0.120 & \\
\hline & 5 & $0.489(\mathrm{H}-5 \rightarrow \mathrm{L}) ; 0.319(\mathrm{H}-7 \rightarrow \mathrm{L}) ;-0.117(\mathrm{H}-2 \rightarrow \mathrm{L}+2)$ & $4.91 / 252$ & 0.165 & \\
\hline & 6 & $-0.153(\mathrm{H}-5 \rightarrow \mathrm{L}+1) ;-0.105(\mathrm{H}-4 \rightarrow \mathrm{L}+2) ;-0.268(\mathrm{H}-1 \rightarrow \mathrm{L}+4)$ & $5.29 / 234$ & 0.126 & \\
\hline & 7 & $-0.132(\mathrm{H}-7 \rightarrow \mathrm{L}) ; 0.194(\mathrm{H}-1 \rightarrow \mathrm{L}+3) ; 0.137(\mathrm{H} \rightarrow \mathrm{L}+7)$ & $5.69 / 217$ & 0.541 & \\
\hline \multirow[t]{5}{*}{ ID3 } & 1 & $0.663(\mathrm{H} \rightarrow \mathrm{L})$ & $2.42 / 512$ & 1.001 & $\pi \rightarrow \pi^{*}$ \\
\hline & 2 & $0.664(\mathrm{H}-1 \rightarrow \mathrm{L}) ; 0.144(\mathrm{H} \rightarrow \mathrm{L}+1)$ & $3.14 / 394$ & 0.359 & \\
\hline & 4 & $-0.120(\mathrm{H}-1 \rightarrow \mathrm{L}) ; 0.654(\mathrm{H} \rightarrow \mathrm{L}+1)$ & $3.45 / 358$ & 0.664 & \\
\hline & 5 & $-0.129(\mathrm{H}-8 \rightarrow \mathrm{L}) ;-0.137(\mathrm{H}-4 \rightarrow \mathrm{L}) ;-0.296(\mathrm{H} \rightarrow \mathrm{L}+2)$ & $3.83 / 323$ & 0.198 & \\
\hline & 6 & $0.445(\mathrm{H}-5 \rightarrow \mathrm{L}+1) ; 0.134(\mathrm{H} \rightarrow \mathrm{L}+4) ; 0.113(\mathrm{H} \rightarrow \mathrm{L}+9)$ & $4.89 / 253$ & 0.163 & \\
\hline
\end{tabular}

${ }^{a}$ the excitation energies of the singlet-state for the dyes; ${ }^{b}$ the oscillator strengths of the singlet-state of the dyes

ciently more positive than the conduction band energy level of $\mathrm{TiO}_{2}\left(E_{\text {cb }}\right.$ is $-2.77 \mathrm{eV}$ for the bare $\mathrm{Ti}_{38} \mathrm{O}_{76}$ cluster as a model for nanocrystalline exposing the anatase (101) surface) $)^{23}$ to inject the electrons from the dyes to the conduction band of $\mathrm{TiO}_{2}$. The energy level of HOMO of the three indoline dyes shift to be positive from ID1, ID2 to ID3, while those of the LUMO shift to be negative. Moreover, with the increase of phenyl number in the donors, the energy gaps between the HOMO and LUMO decrease from 2.83, 2.62, to $2.56 \mathrm{eV}$ for ID1, ID2, and ID3 in order.

\subsection{Optical absorption spectra}

In order to obtain the microscopic information about the electronic transitions, the corresponding molecular orbital properties were checked, the computed excitation energies, electronic transition configurations, and oscillator strengths along with the main excitation configuration for the dyes are listed in Table 3. The simulated UV-Vis absorption spectra of ID1-ID3 are given in Fig.5, and the relative calculated absorption peaks are listed in Table 4. The major electronic absorption bands are assigned to those excitations with significant oscillator

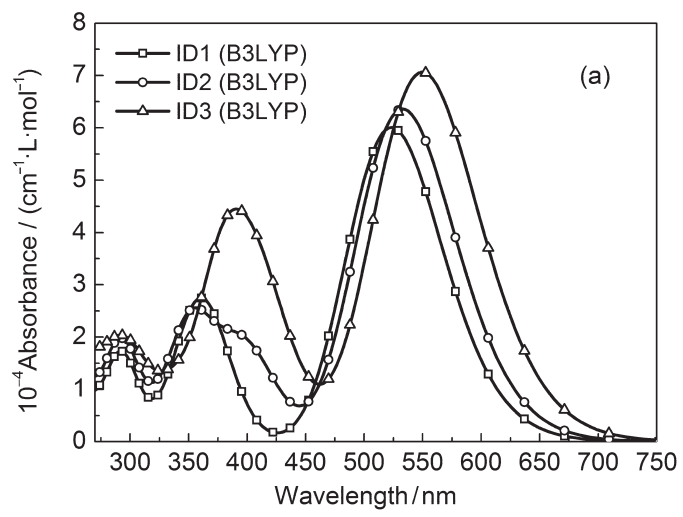

strengths. The first optically allowed electronic transition of ID1-ID3 clearly corresponds to the HOMO-LUMO transition possessing high transition intensity. As the HOMO and the LUMO are of the $\pi$ and $\pi^{*}$ type, the HOMO-LUMO transition can be classified as a $\pi-\pi^{*}$ intramolecular charge transfer. It can be found that the calculated absorption spectra of dyes agree with those of the experiment, ${ }^{11,12}$ although there is some discrepancy which may be attributed to the DFT and the solvent effects; and the hybrid functional PBE1PBE is more suitable than B3LYP for calculation of electronic absorption spectra of the indoline dyes, consulting from Fig.5 and Table 4. So the absorption spectra discussed in the following in this paper are all simulated with PBE1PBE. Fig.5 shows that ID1-ID3 have broad absorption bands (located in the ranges of 350-400 nm and 450-600 nm) and high molar extinction coefficients $(4.6 \times$ $\left.10^{4}-6.3 \times 10^{4} \mathrm{~cm}^{-1} \cdot \mathrm{L} \cdot \mathrm{mol}^{-1}\right)$ in the long wavelength range, which is advantageous for light harvesting. Within the scope of wavelength analyzed, the simulated spectra of ID1 and ID2 show three maxima, while the simulated spectrum of ID3 is composed of two bands. Furthermore, the locations of the ab-

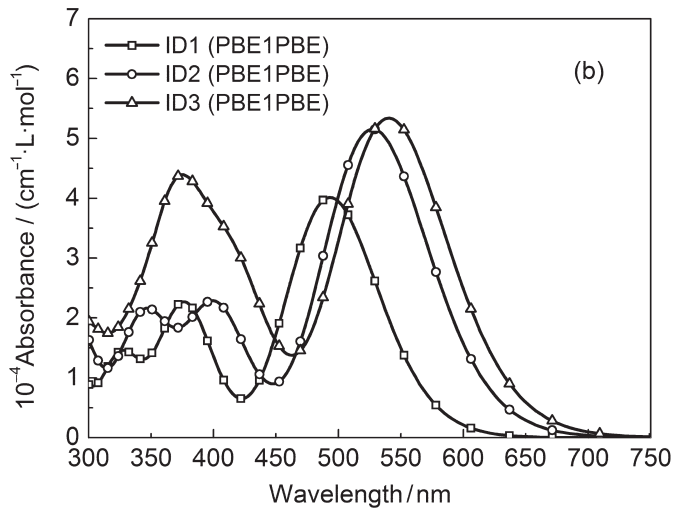

Fig.5 Simulated UV-Vis spectra of ID1-ID3 with hybrid functionals (a) B3LYP and (b) PBE1PBE 
Table 4 Experimental and simulated absorption peaks calculated with B3LYP and PBE1PBE hybrid functionals

\begin{tabular}{|c|c|c|c|c|c|c|c|}
\hline & \multicolumn{2}{|c|}{ B3LYP } & \multicolumn{2}{|c|}{ PBE1PBE } & \multicolumn{2}{|c|}{ Experiment } & \multirow{2}{*}{$\begin{array}{c}\eta / \% \\
\text { (indoline/N3) }\end{array}$} \\
\hline & $\lambda_{\max } / \mathrm{nm}$ & $10^{-4} \varepsilon /\left(\mathrm{cm}^{-1} \cdot \mathrm{L} \cdot \mathrm{mol}^{-1}\right)$ & $\lambda_{\max } / \mathrm{nm}$ & $10^{-4} \varepsilon /\left(\mathrm{cm}^{-1} \cdot \mathrm{L} \cdot \mathrm{mol}^{-1}\right)$ & $\overline{\lambda_{\max } / \mathrm{nm}}$ & $\varepsilon /\left(\mathrm{cm}^{-1} \cdot \mathrm{L} \cdot \mathrm{mol}^{-1}\right)$ & \\
\hline ID1 & 493 & 4.00 & 471 & 4.6 & $483^{a}$ & $4.33 \times 10^{4 a}$ & $\sim 5.6 / \sim 6.3^{12}$ \\
\hline ID2 & 529 & 5.15 & 502 & 5.8 & $\mathrm{NA}^{\mathrm{b}}$ & $\mathrm{NA}^{\mathrm{b}}$ & $5.5 / 6.3^{11}$ \\
\hline ID3 & 541 & 5.34 & 512 & 6.2 & $491^{\mathrm{c}}$ & $5.58 \times 10^{4 \mathrm{c}}$ & $6.1 / 6.3^{11}$ \\
\hline
\end{tabular}

measured in ethanol in Ref.12; ${ }^{\mathrm{b}}$ not available but similar to those of ID3 in Ref.11; ${ }^{\mathrm{c}}$ measured in tert-butyl alcohol/acetonitrile mixture

solution with the volume ratio of 1:1 in Ref.11

sorption bands have a red-shift from ID1, ID2 to ID3 (the maximum absorption peaks for them center at 469, 502, and 512 $\mathrm{nm}$, respectively) with the phenyl number increasing in the donor moieties. The shape variation and red-shift of the peak described above are closely related to the change of electronic structures of the dyes, which may be attributed to the enhanced conjugation in the molecules induced by the increasing phenyl moiety (confirmed by the NBO analysis).

\subsection{Theoretical parameters to judge electrochemical performance of indoline dyes}

In DSSCs, the incident monochromatic photo-to-current conversion efficiency (IPCE) is one of the most important factors to evaluate the performance of the dyes. As expressed in Eq. (1), ${ }^{6,25}$

$\mathrm{IPCE}=\mathrm{LHE} \cdot \varphi_{\mathrm{inj}} \cdot \eta_{\mathrm{c}}$

IPCE is composed of three segments: light harvesting efficiency (LHE), quantum yield of charge injection $\left(\varphi_{\text {inj }}\right)$, and electron collection efficiency $\left(\eta_{c}\right)$. LHE relates to the absorption spectrum response of dye molecules, including the spectrum location and molar extinction coefficient. $\varphi_{\text {inj }}$ depends on the energy gap between the LUMO energy level of dyes $\left(E_{\text {LUмо }}\right)$ and the conduction band edge of $\mathrm{TiO}_{2}\left(E_{\mathrm{cb}}\right)$, which is denoted as the driving force of the electron injection. ${ }^{26}$ Thus, the absorption spectra and LUMO energy level of dyes act as two criteria to the electrochemical performance of the dyes by determining the IPCE value.

\subsubsection{Effect of the absorption band on the electrochemical performance}

It is well known that red-shift of absorption spectra of dyes are advantageous to the light harvesting in DSSCs. Furthermore, as in Eq.(2), ${ }^{6}$

$$
\mathrm{LHE}=1-10^{-\Gamma \sigma(\lambda)}
$$

where $\Gamma$ is the number of moles of seneitizer per square centimeter of projected surface area of the film; $\sigma$ is the absorption cross section obtained from the decadic extinction coefficient (units of $\mathrm{mol}^{-1} \cdot \mathrm{L} \cdot \mathrm{cm}^{-1}$ ) by multiplication with $1000 \mathrm{~cm}^{3} \cdot \mathrm{L}^{-1} ; \lambda$ is the absorption wavelength. the molar extinction coefficient of dye molecule is proportional to the LHE. Consequently, the location of absorption band and the corresponding molar extinction coefficient together affect the overall efficiency of cells by their contribution to the light harvesting efficiency. Where, $\sigma$ is the function of molar extinction coefficient of dye molecule, which is obtained from the decadic extinction coefficient (units of $\mathrm{mol}^{-1} \cdot \mathrm{L} \cdot \mathrm{cm}^{-1}$ ) by multiplication with $1000 \mathrm{~cm}^{3}$. $\mathrm{L}^{-1}$.
Table 4 shows from ID1, ID2, to ID3, with increase of phenyl number in the donor, the absorption bands red-shift to longer wavelength while the absorbency of the peaks increases gradually meaning much bigger molar extinction coefficient of the dyes in the studied wavelength $(\lambda)$ ranges. With longer absorption wavelength as well as bigger molar extinction coefficient, ID3 has higher LHE value than ID1 and ID2, and thus higher efficiency $(6.1 \%)$ than ID1 and ID2 (5.5\% and 5.6\%) compared with $6.3 \%$ for N3. However, the light harvesting efficiency of ID2 is higher than that of ID1, while the efficiency of cells of ID2 is lower than that of ID1. It demonstrates that the light harvesting efficiency of the dye is not the only factor to determine the efficiency of cells, and the abnormal phenomenon between the light harvesting efficiency and overall efficiency of the cells of ID1 and ID2 will be elaborated below.

\subsubsection{Effect of the LUMO energy level on the electrochemical performance}

From Fig.4, it shows that the energy gaps between the $E_{\text {Lumo }}$ of indoline dyes and $E_{\mathrm{cb}}$ are $0.35,0.27$, and $0.24 \mathrm{eV}$, respectively for ID1, ID2, and ID3. The driving force for electron injection decreases in the same order. The driving force of ID1 is larger than that of ID2, leading to the higher light to energy efficiency of ID1. Therefore, the theoretical order of the light-toenergy efficiency of three indoline dyes is ID3 $>$ ID1 $>$ ID2, considering of the mutual contribution of absorption spectra and the LUMO energy levels of the dyes, which is consistent with the experimental results ${ }^{11,12}$ listed in Table 4.

\section{Conclusions}

The electronic structures and absorption spectra of the dyes ID1-ID3 containing different donors were investigated by TDDFT calculation, at the B3LYP and PBE1PBE levels with the 6-31 $\mathrm{g}(d)$ basis set, respectively. The calculated geometric characters indicate that the strong conjugated effect is formed in the dyes, which is very helpful for efficient electron transfer. The NBO results suggest that the introduction of more phenyl moieties leads to a decrease in the electron-donating capability of the donor, but an increased conjugation and stabilization in the molecules. The electron population indicates that the energy level location of dyes fits the electron injection process from the excited dyes to the semiconductor in DSSCs. The simulated UV-Vis absorption spectra show qualitative agreement with the experimental results. The indoline dyes have broad absorption bands and high molar extinction coefficients in the long wavelength range, revealing the good light harvesting effi- 
No.8 LIANG Gui-Jie et al:: Effect of Donor Moieties on the Electronic Structures and Absorption Spectra of Indoline Dyes 1891

ciency.

The absorption spectra and LUMO energy level determine the photovoltaic performance of the dyes by affecting the light harvesting and electron injection efficiencies, respectively. Through the comparative analysis of electronic structures, spectra and photovoltaic properties, ID3 with long absorption band as well as favorable LUMO energy level has been theoretically proved to be the most effective one for DSSCs among ID1ID3, which is consistent with the experimental results.

\section{References}

(1) Oregan, B.; Grätzel, M. Nature 1991, 353, 737. doi: 10.1038/ 353737a0

(2) Papageorgiou, N.; Grätzel, M.; Infelta, P. P. Sol. Energy Mater. Sol. Cells 1996, 44, 405. doi: 10.1016/S0927-0248(96)00050-5

(3) Hagfeldt, A.; Grätzel, M. Accounts Chem. Res. 2000, 33, 269. doi: $10.1021 / \operatorname{ar} 980112 \mathrm{j}$

(4) Wang, Z. S.; Li, F. Y.; Huang, C. H. J. Phys. Chem. B 2001, 105, 9210. doi: 10.1021/jp010667n

(5) Kuang, D.; Klein, C.; Snaith, H. J.; Humphry-Baker, R.; Zakeeruddin, S. M.; Grätzel, M. Inorg. Chim. Acta 2008, 361, 699. doi: 10.1016/j.ica.2007.05.031

(6) Nazeeruddin, M. K.; Pechy, P.; Renouard, T.; Zakeeruddin, S. M.; Humphry-Baker, R.; Comte, P.; Liska, P.; Cevey, L.; Costa, E.; Shklover, V.; Spiccia, L.; Deacon, G. B.; Bignozzi, C. A.; Grätzel, M. J. Am. Chem. Soc. 2001, 123, 1613. doi: 10.1021/ ja003299u

(7) Guo, M.; Diao, P.; Ren, Y. J.; Meng, F.; Tian, H.; Cai, S. M. Sol. Energy Mater. Sol. Cells 2005, 88, 23. doi: 10.1016/j.solmat. 2004.10.003

(8) Shiga, T.; Motohiro, T. Thin Solid Films 2008, 516, 1204. doi: 10.1016/j.tsf.2007.05.009

(9) Giribabu, L.; Kumar, C. V.; Reddy, V. G.; Reddy, P. Y.; Rao, C. S.; Jang, S. R.; Yum, J. H.; Nazeeruddin, M. K.; Grätzel, M. Sol. Energy Mater. Sol. Cells 2007, 91, 1611. doi: 10.1016/j.solmat. 2007.05.004

(10) Enea, O.; Moser, J.; Grätzel, M. J. Electroanal. Chem. 1989, 259, 59. doi: 10.1016/0022-0728(89)80038-5

(11) Horiuchi, T.; Miura, H.; Uchida, S. Chem. Commun. 2003, 3036.
(12) Horiuchi, T.; Miura, H.; Uchida, S. J. Photochem. Photobiol. A 2004, 164, 29. doi: 10.1016/j.jphotochem.2003.12.018

(13) Onwona-Agyeman, B.; Kaneko, S.; Kumara, A.; Okuya, M.; Murakami, K.; Konno, A.; Tennakone, K. Jpn. J. Appl. Phys. Part 2 2005, 44, L731.

(14) Matsui, M.; Ito, A.; Kotani, M.; Kubota, Y.; Funabiki, K.; Jin, J.; Yoshida, T.; Minoura, H.; Miura, H. Dyes Pigments 2009, 80, 233. doi: 10.1016/j.dyepig.2008.07.010

(15) Ham, H. W.; Kim, Y. S. Thin Solid Films 2010, 518, 6558. doi: 10.1016/j.tsf.2010.03.048

(16) Le Bahers, T.; Pauporte, T.; Scalmani, G.; Adamo, C.; Ciofini, I. Phys. Chem. Chem. Phys. 2009, 11, 11276.

(17) Téllez S, C. A.; Hollauer, E.; Giannerini, T.; Pais da Silva, M. I.; Mondragón, M. A.; Rodríguez T, J. R.; Castaño, V. M. Spectrochim. Acta A 2004, 60, 2171. doi: 10.1016/j.saa. 2003.11.011

(18) Becke, A. D. J. Chem. Phys. 1993, 98, 5648. doi: 10.1063/ 1.464913

(19) Tiwary, A. S.; Mukherjee, A. K. J. Mol. Struct. -Theochem 2008, 859, 107. doi: 10.1016/j.theochem.2008.03.015

(20) Perdew, J. P.; Burke, K.; Ernzerhof, M. Phys. Rev. Lett. 1996, 77, 3865. doi: 10.1103/PhysRevLett.77.3865

(21) Cossi, M.; Barone, V.; Cammi, R.; Tomasi, J. Chem. Phys. Lett. 1996, 255, 327. doi: 10.1016/0009-2614(96)00349-1

(22) Frisch, M. J.; Trucks, G. W.; Schlegel, H. B.; et al. Gaussian 03, Revision E.01; Gaussian Inc.: Wallingford, CT, 2004.

(23) Xu, J.; Zhang, H.; Liang, G. J.; Wang, L. X.; Xu, W. L.; Cui, W. G.; Li, Z. C. J. Serb. Chem. Soc. 2010, 75, 259. doi: 10.2298/ JSC1002259X

(24) Kuang, D.; Uchida, S.; Humphry-Baker, R.; Zakeeruddin, S. M.; Grätzel, M. Angewandte Chemie 2008, 47, 1923. doi: 10.1002/ anie. 200705225

(25) Yang, R.; Wang, W. B.; Hou, Y. J.; Xiao, X. R.; Zhang, B. W.; Cao, Y. Acta Phys. -Chim. Sin. 1998, 14, 520. [杨 蓉, 王维 波, 候原军, 肖绪瑞, 张宝文, 曹 怡. 物理化学学报, 1998, 14, 520.] doi: 10.3866/PKU.WHXB19980608

(26) Asbury, J. B.; Hao, E.; Wang, Y. Q.; Ghosh, H. N.; Lian, T. Q. J. Phys. Chem. B 2001, 105, 4545. doi: 10.1021/jp003485m 